\title{
IMPLEMENTASI WEIGHT PRODUCT (WP) UNTUK PEMILIHAN BUBUR BAYI INSTAN USIA 6 BULAN+
}

\author{
Erene Gernaria Sihombing1, Christopher Dynoㄹ, Ester Arisawati ${ }^{3}$, Linda Sari Dewi ${ }^{4}$, \\ Rinawati $^{5}$ \\ STMIK Nusamandiri \\ Jl. Jatiwaringin Raya No.2 Jakarta Timur \\ 1.erene.egs@nusamandiri.ac.id \\ 2. dynochri0603@bsi.ac.id \\ 3. ester.err@nusamandiri.ac.id \\ 4. linda.lrw@nusamandiri.ac.id \\ 5. rinawati.riw@nusamandiri.ac.id
}

\begin{abstract}
Instant baby porridge is one of the preferred foods for babies that are used at the age of six months and above and baby porridge or also known as solid food is a very decisive step to meet a baby's nutritional needs, the problem of fulfilling nutrition for all age groups is still not resolved at this time. The cause of malnutrition can be seen from one of the factors that are difficult to eat, the problem of difficulty eating can be seen in toddlers and this problem if not resolved quickly can affect the growth and development of toddlers due to nutritional deficiencies. Parents' desire to meet their children's nutritional needs is often in inappropriate ways, such as by promising a reward in the form of their favorite meal if the child shows good behavior, so that the child does not consume healthy food and ultimately results in bad food behavior for the child. To solve the above problems, a decision support system method is applied, namely the weighted product (WP) with the aim that parents can easily and quickly choose baby porridge food, so that there are no mistakes in meeting the nutritional needs of their children. The results obtained in the calculation of the Weighted Product Method which consists of several calculation stages, starting from determining alternatives and criteria, baby porridge selection criteria, weight importance level, criteria weighting, vector calculation to ranking are products for selecting baby porridge, there are 2 best alternatives, namely A11 with a value of 0.09390 and A12 with a value of 0.09390.
\end{abstract}

Keywords: weight product, instant baby porridge

\section{Abstrak}

Bubur bayi instan salah satu makanan pilihan bayi yang digunakanan pada usia enam bulan keatas dan bubur bayi atau juga disebut dengan makanan padat merupakan langkah yang sangat menentukan untuk memenuhi suatu kebutuhan gizi bayi, permasalahan pemenuhan gizi dari seluruh kelompok umur masih belum bisa diselesaikan pada saat ini. Menyebabkan gizi yang kurang dapat dilihat dari salah satu faktor sulit makan, masalah sulit makan dapat dilihat pada balita dan masalah tersebut jika tidak diselesaikan dengan cepat dapat mempengaruhi pertumbuhan dan perkembangan balita 
dikarenakan kekurangan nutrisi. Keinginan para orang tua untuk memenuhi kebutuhan nutrisi anaknnya sering kali dalam pemberian makanan dengan cara yang kurang tepat seperti dengan menjanjikan hadiah berupa makan kesukaannya jika anak menunjukkan perilaku yang baik, sehingga anak tidak mengkonsumsi makanan sehat dan akhirnya mengakibatkan perilaku makanan yang tidak baik bagi anak. Untuk menyelesaikan permasalahan diatas, maka diterapkan metode sistem penunjang keputusan yaitu weighted product (WP) dengan tujuan agar para orang tua dengan mudah dan cepat dalam memilih makanan bubur bayi, sehingga tidak tejadi kesalahan dalam memenuhi kebutuhan gizi anaknya. Adapun hasil yang diperoleh dalam perhitungan Metode Weighted Product yang terdiri dari beberapa tahap perhitungan, mulai dari penentuan alternatif dan kriteria, kriteria seleksi bubur bayi, kingkat kepentingan bobot, pembobotan kriteria, perhitungan vektor hingga perangkingan adalah produk untuk penyeleksian bubur bayi didapatkan 2 alternatif terbaik yaitu A11 dengan nilai 0,09390 dan A12 dengan nilai 0,09390.

Kata kunci: weight product, bubur bayi instan

\section{PENDAHULUAN}

Sistem Pendukung Keputusan adalah suatu implementasi dari sistem informasi yang digunakan untuk membantu para pimpinan ketika proses pengambilan keputusan [1]. Sistem Pendukung Keputusan dapat digunakan dalam melakukan pengambilan keputusan dari beberapa kriteria yang sudah ada atau ditetapkan [2]. Pengambilan keputusan dapat dilakukan dengan melalui pendekatan sistematis terhadap permasalahan dari proses pengumpulan data sampai menjadi informasi serta adanya bermacam-macam faktor yang perlu dipertimbangkan dalam pengambilan keputusan [3].

Salah satu metode FMADM yang terkenal yaitu metode Weighted Product (WP). Metode Weighted Product (WP) banyak diterapkan dalam pengambilan keputusan dikarenakan metode yang sederhana dengan menginputkan semua faktorfaktor dan komputasinya yang cepat [4], serta dapat memilih alternatif-alternatif terbaik dari beberapa alternatif [5]. Pada metode Weighted Product (WP) menggunakan perkalian dalam menghubungkan rating atribut dan pada rating setiap atribut dipangkatkan terlebih dahulu dengan bobot atribut yang berkaitan [6] dan hasil perkalian tersebut belum bermakna jika belum dibandingkan (dibagi) dengan nilai standart [7].

Gizi menjadi permasalahan dunia yang masih belum dapat diselesaikan hingga saat ini. Usia bayi dan balita sangat menjadi perhatian karena pada saat ini terjadi pertumbuhan dan perkembangan yang sangat menentukan kualitas kehidupan mereka selanjutnya. Jika keluarga bisa melaksanakan tugas tersebut dengan baik, maka kebutuhan akan nutrisi anak menjadi terpenuhi dengan baik. Pengungkapan bahwa dalam pemberian makanan bisa dilihat dari kontrol makanan anak (controlling), pemberian contoh pada saat konsumsi makanan (modelling), keterlibatan anak dalam melakukan persiapan dan memilih makan yang akan dikonsumsi (involvement) [8].

Makanan pendamping ASI sangat diperlukan ketika bayi berusia 6 bulan ke atas. ASI sudah merupakan makanan pokok bagi bayi, namun ketika usia beranjak 6 bulan ke atas, bayi sudah sangat memerlukan nutrisi lain selain ASI. Nutrisi itulah yang didapatkan dari makanan pendamping asi. Selain sebagai tambahan nutrisi pemberian 
MPASI ini bisa melatih bayi untuk mulai mencerna makanan selain ASI. Pemberian pun tidak boleh sembarangan dan pemberian produk makanan bubur atau mengolah bubur sendiri harus sangat dipertimbangkan, agar yang diberikan tidak merugikan merugikan bayi atau dapat menimbulkan beberapa resiko bagi bayi [9].

Membeli susu formula sering kali diansumsikan kegiatan wajib bagi ibu yang melahirkan atau mempunyai bayi baru [10] dan banyaknya jenis merek susu balita di pasaran saat ini dan dengan memiliki keunggulan atau kelebihan dan juga memiliki bermacam-macam karakteristik dari setiap produk yang ditawarkan, membuat konsumen tidak bisa menentukan pilihan dalam memilih produk yang cocok untuk dikonsumsi [11].

\section{METODOLOGI PENELITIAN}

\subsection{Tahapan Penelitian}

Metodologi penelitian merupakan tahap-tahap penelitian yang sistematis untuk membantu penelitian menjadi terarah dengan baik.

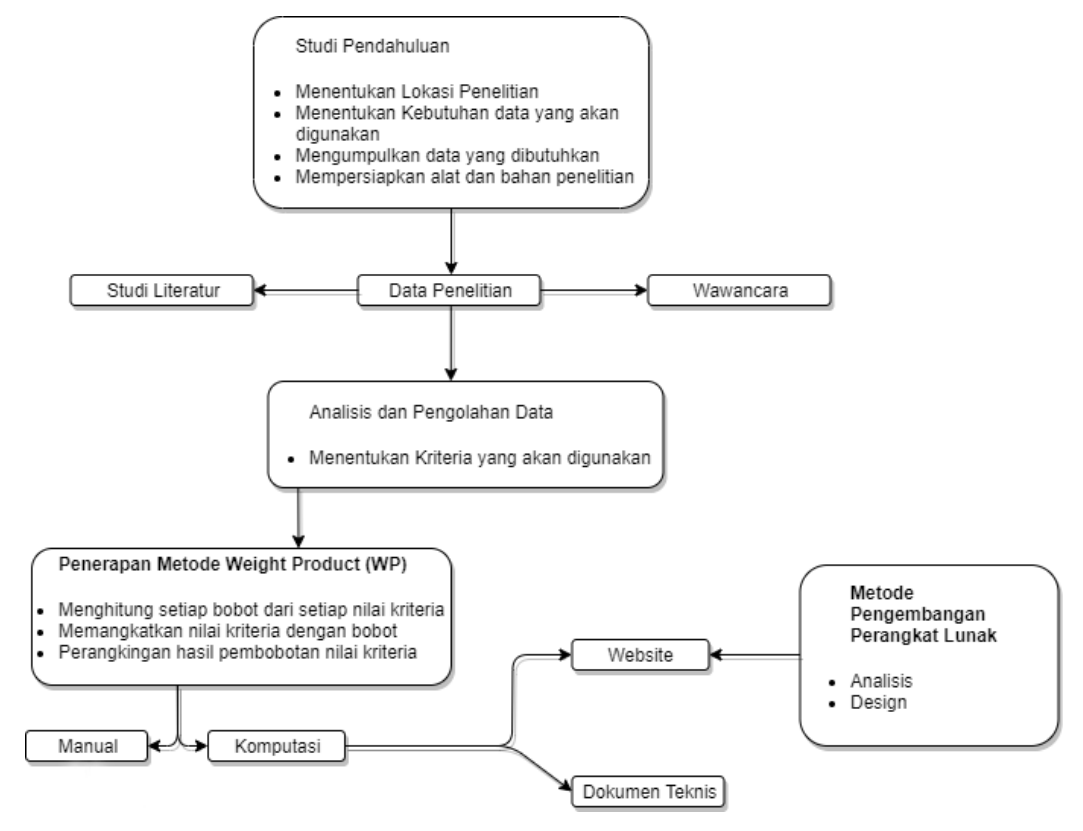

Gambar 2.1 Tahapan Penelitian

berikut:

Adapun tahapan yang akan dilakukan dalam proses penelitian ini sebagai

a. Studi Pendahuluan

Studi pendahuluan menjelaskan beberapa tahap rancangan yang juga merupakan studi literatur dan observasi yang akan dilakukan pada sistem sebagai berikut:

1) Menentukan kebutuhan data yang digunakan

Data yang dibutuhkan pada penelitian ini adalah data Website resmi perusahaan bubur instan.

2) Mengupulkan data yang dibutuhkan 
Data yang telah ditentukan di atas selanjutnya dikumpulkan untuk di analisis untuk menentukan kriteria dan di proses dengan menerapkan metoda Weigted Product (WP).

3) Alat dan bahan yang dipersiapkan pada penelitian ini adalah perangkat yang digunakan untuk membuat sistem pendukung keputusan berbasis web, serta data-data yang telah dikumpulkan untuk diolah ke tahap perhitungan dengan menggunakan metode Weighted Product.

b. Data Penelitian

1) Studi Literatur

Studi literatur dalam sebuah penelitian untuk mendapatkan gambaran yang menyeluruh tentang apa yang sudah dikerjakan orang lain dan bagaimana orang mengerjakannya, kemudian seberapa berbeda penelitian yang akan kita lakukan. Pada tahap ini, studi literatur dilakukan dengan mencari referensi dari paper, textbook, dan jurnal.

2) Pengumpulan Data

Tahap pengumpulan data ini penulis menggunakan dua cara pengumpulan data yaitu:

a) Data primer : Pengumpulan data langsung mengambil data dari website Kalbe Store mengenai keadaan keaslian data dan komposisi produk serta kebutuhan ibu dan anak mengenai Sistem Pendukung Keputusan buru bayi usia 6 bulan keatas.

b) Data sekunder : Pengumpulan data berdasarkan penelusuran literatur, buku, jurnal dan referensi pendukung penelitian.

c. Pengolahan Data

Pada tahap ini, data yang telah ditentukan akan dianalisis guna melengkapi dan memenuhi kebutuhan sistem yaitu dengan cara:

1) Menentukan Kriteria yang akan digunakan dalam pemilihan bubur bayi usia 6 bulan+ yang akan direkomendasikan untuk hasil terbaik sesuai degan asupan kebutuhan yang sedang orang tua bayi butuhkan untuk buah hatinya. Pada penilian ini Kriteria yang digunakan yaitu Protein, Karbohidrat, Lemak, Zat Besi, Zing, dan Harga.

2) Menentukan Alternatif yang akan digunakan sebagai bahan penelitian di dalam pemilihan bubur bayi usia 6 bulan+ yang akan direkomendasikan untuk pilihan bubur bayi terbaik. Dari data yang dikumpulkan dari website Kalbe Store alternatif yang digunakan yaitu farian komposisi bubur bayi milna, yaitu; Bubur Bayi Reguler, Bayi Organic, Bayi Wgain dan Bayi GoodMil.

d. Penerapan Metode WP

Setelah data di analisis, kemudian data di proses dengan menggunakan metode WP dengan langkah sebagai berikut:

1) Menghitung bobot dari setiap nilia kriteria

2) Memangkatkan nilai kriteria dengan bobot

3) Pe-rangkingan hasil pembobotan nilai kriteria

Penerapan Metode WP digunakan dalam proses perhitungan nilai dari Kriteria secara keseluruhan (Protein, Karbohidrat, Lemak, Zat Besi, Zing, dan 
Harga) yang hasilnya dapat menentukan Bubur Bayi mana yang akan direkomendasikan bagi ibu dari bayi usia 6 bulan+ yang sesuai dengan kategori kriteria telah dipilih. Penjelasan selengkapnya mengenai penerapan metode WP sebagai penentu hasil keputusan dalam penelitian ini berasal dari Bubur Bayi yang akan direkomendasikan untuk bayi usia 6 bulan+ akan dijabarkan pada.

\subsection{Instrumen Penelitian}

Instrumen penelitian adalah semua alat yang digunakan untuk mengumpulkan, memeriksa, dan menyelidiki suatu masalah, atau mengumpulkan, mengelola, menganalisa dan menyajikan data-data secara sestematis serta objektif dengan tujuan memecahkan suatu persoalan atau menguji suatu hipotesis. Jadi, semua alat yang bisa mendukung suatu penelitian bisa disebut instrumen penelitian. Adapun beberapa instrumen yang dipakai penulis dalam penelitian ini adalah sebgai berikut:

a. Instrumen Pokok

Sebagai instrumen dapat berhubungan langsung dengan responden yaitu HRD Kalbe Store.

b. Instrumen Penunjang

Wawancara dilakukan untuk mendapatkan data-data tentang produk bubur bayi melalui website resmi kalbe store.

\subsection{Metode Analisis Data}

Dalam penelitian ini, menggunakan metode pengambilan keputusan yang diperhitungkan secara kuantitatif (perhitungan matematika sesuai dengan rumus Weighted Product) merupakan suatu analisa data yang dipergunakan apabila kesimpulan-kesimpulan yang diperoleh dapat dibuktikan dengan angka-angka dan juga dalam perhitungan dipergunakan rumus yang ada hubungannya dengan analisis penulis. Dalam hal ini akan dipergunakan metode Weighted Product (WP).

\subsection{Pengolahan Data dengan Perhitungan Weighted Product (WP)}

Pada tahapan perhitungan melalui metode Weighted Product (WP), berikut ini beberapa data yang dibutuhkan dalam membuat sistem:
a. Data jenis-jenis bubur bayi milna usia 6 bulan+
b. Data Rasa bubur bayi milna usia 6 bulan+
c. Data kandungan protein pada bubur bayi milna usia 6 bulan+
d. Data kandungan karbohidrat pada bubur bayi milna usia 6 bulan+
e. Data kandungan lemak pada bubur bayi milna usia 6 bulan+
f. Data kandungan zat besi pada bubur bayi milna usia 6 bulan+
g. Data kandungan zing pada bubur bayi milna usia 6 bulan+
h. Data harga produk pada bubur bayi milna usia 6 bulan+

Setelah memperoleh data tersebut, selanjutnya dibutuhkan data perhitungan, data-data tersebut diolah untuk dilakukan perhitungan dengan menggunakan metode Weighted Product (WP). Dalam proses perhitungan terdapat 4 tahap yang harus diselesaikan, antara lain: 
a. Tahap 1

Pertama, menentukan beberapa parameter dengan menganti data pemilihan alternatif dengan menggunakan variable R1, R2, R3, dan R4 untuk menjadi dasar pemilihan bubur bayi milna. Dibawah ini merupakan parameter pilihan pada SPK bubur bayi pada usia 6 bulan + adalah sebagai berikut :

R1 : Bubur Bayi Reguler

R2 : Bubur Bayi Organic

R3 : Bubur Bayi WGain

R4 : Bubur Bayi GoodMil

Langkah selanjutnya menentukan bobot nilai sebagai berikut:

Nilai 5 : Sangat penting

Nilai 4 : Penting

Nilai 3 : Cukup penting

Nilai 2 : Kurang penting

Nilai 1 : Tidak penting

Selanjutnya adalah menentukkan kriteria yang akan dibuat pada SPK bubur bayi milna antara lain :

1) Protein (C1)

Menilai berapa banyak banyak protein yang terkandung pada bubur bayi

2) Karbohidrat (C2)

Menilai berapa banyak banyak karbohidrat yang terkandung pada bubur bayi

3) Lemak (C3)

Menilai berapa banyak banyak lemak yang terkandung pada bubur bayi

4) Zat Besi (C4)

Menilai berapa banyak banyak zat besi yang terkandung pada bubur bayi

5) Zing/Seng (C5)

Menilai berapa banyak banyak zing/seng yang terkandung pada bubur bayi .

6) Harga (C6)

Menilai harga yang ditawarkan, termasuk dalam murah dengan bobot nilai (sangat penting), sedang dengan bobot nilai (cukup penting), relatif dengan bobot nilai (kurang penting), dan terakhir mahal dengan bobot nilai (tidak penting).

Kemudian setelah didapatkan 6 kriteria tersebut, lakukan pemilihan tipe kritera sebagai syarat dalam melakukan perhitungan untuk tahap selanjutnya. Protein, karbohidrat, lemak, zat besi, zing dikelompokkan kedalam tipe kriteria benefit, dan harga termasuk kedalam tipe kriteria cost. Setalah dilakukan penentuan tipe kriteria, lakukan penilaian bobot pada alternatif untuk menjadi dasar perhitungan nilai bobot dilambangkan dengan variable (W).

b. Tahap ke 2

Langkah ke 2 adalah dengan melakukan perbaikan bobot, sehingga total bobot I?wj =1 dengan cara :

$$
\mathrm{W}_{\mathrm{J}}=\frac{W j}{\sum W j}
$$




\section{c. Tahap ke 3}

Setelah mendapatkan hasil wj1 hingga wj6 dilanjutkan langkah ke 3 yaitu menentukan nilai vektor $S$ yang dapat dihitung dengan menggunakan rumus berikut :

$$
\mathrm{S}_{\mathrm{i}}=\prod_{J=1}^{n} X_{i j} \mathrm{w}_{\mathrm{j}}
$$

d. Tahap ke 4

Setelah mendapatkan hasil S1 hingga S4 kemudian dilanjutkan ke langkah ke 4 yaitu menentukkan nilai vector yang akan digunakan untuk menghitung presentasi (Vi) untuk dapat memperoleh hasil perangkingan dengan rumus :

$$
\mathrm{V}_{\mathrm{i}}=\frac{\prod_{J=1}^{n} X_{i j} \mathrm{wj}}{\prod_{J=1}^{n}\left(X_{j} * \mathrm{wj}\right.}
$$

\section{HASIL DAN PEMBAHASAN}

\subsection{Analisis Data}

Penelitian ini akan membahas sistem pendukung yang diharapkan dapat membantu Para Orang tua Bayi dalam pemilihan Bubur Bayi Usia bulan+ secara efisien. Dalam penyeleksian Bubur Bayi terdapat beberapa tahapan, yaitu:

a. Identifikasi Masalah

Kesulitan dalam menentukan bubur bayi yang terbaik berdasarkan kebutuhan bayi usia 6 bulan+.

b. Studi Pustaka

Dilakukannya studi pustaka dengan mengumpulkan bahan dari berbagai sumber seperti media jurnal dan dari beberapa buku yang membahas tentang Weighted Product (WP).

c. Mengolah data perhitungan

Dalam mengolah data perhitungan untuk penyeleksian Bubur Bayi terbaik untuk bayi usia 6 bulan+ menggunakan metode Weighted Product (WP) diperlukannya kriteria-kriteria dan bobot sehingga akan didapat alternatif terbaik. Dalam penyelesaian perhitungan sebagai berikut:

\subsubsection{Data Alternatif}

Tabel alternatif dan krieria merupakan data Bubur Bayi pada spesifikasi kemasan yang akan diseleksi untuk menjadi pilihan bubur bayi yang sesuai bagi bayi usia 6 bulan+ berdasarkan data produk bubur bayi dan Angka Kecukupan Gizi yang dibutuhkan bagi bayi. 
Tabel 3.1 Tabel Alternatif

\begin{tabular}{ll}
\hline Alternatif & Rasa \\
\hline A1 & Rasa Pisang Stroberi \\
A2 & Beras Merah Pisang \\
A3 & Cah Daging Kacang Polong \\
A4 & Tim Hati Ayam Bayam \\
A5 & Sop Ayam Wortel \\
A6 & Pisang \\
A7 & Kacang Hijau \\
A8 & Beras Merah \\
A9 & Ayam Bayam \\
A10 & Ayam Sayur \\
A11 & Beras Merah Pisang \\
A12 & Wortel Labu \\
A13 & Beras Merah Ayam \\
A14 & Beras Merah \\
\hline
\end{tabular}

Tabel 3.2 Kriteria Bubur Bayi

\begin{tabular}{|c|c|c|c|c|c|c|c|}
\hline $\begin{array}{c}\text { Kategori Pemilihan } \\
\text { Alternatif }\end{array}$ & Rasa & $\begin{array}{c}\text { Protei } \\
\text { n } \\
\text { (pers } \\
\text { en } \\
\text { AKG) }\end{array}$ & $\begin{array}{c}\text { Karbohi } \\
\text { drat } \\
\text { (gram) }\end{array}$ & $\begin{array}{c}\text { Lema } \\
\mathbf{k} \\
\text { (gram } \\
\text { ) }\end{array}$ & $\begin{array}{c}\text { Zat Besi } \\
\text { (persen } \\
\text { AKG) }\end{array}$ & $\begin{array}{c}\text { Zing/se } \\
\text { ng } \\
\text { (persen } \\
\text { AKG) }\end{array}$ & Harga \\
\hline $\begin{array}{c}\text { Bubur bayi Reguler } \\
6 \text { bulan }+\end{array}$ & $\begin{array}{c}\text { Rasa Pisang } \\
\text { Stroberi }\end{array}$ & 30 & 37 & 4.5 & 40 & 40 & 13.500 \\
\hline $\begin{array}{c}\text { Bubur bayi Reguler } \\
6 \text { bulan }+\end{array}$ & $\begin{array}{l}\text { Beras Merah } \\
\text { Pisang }\end{array}$ & 30 & 36 & 4.5 & 40 & 35 & 13.500 \\
\hline $\begin{array}{c}\text { Bubur bayi Reguler } \\
6 \text { bulan }+\end{array}$ & $\begin{array}{c}\text { Cah Daging } \\
\text { Kacang Polong }\end{array}$ & 30 & 37 & 4.5 & 45 & 40 & 13.500 \\
\hline $\begin{array}{c}\text { Bubur bayi Reguler } \\
6 \text { bulan }+\end{array}$ & $\begin{array}{c}\text { Tim Hati Ayam } \\
\text { Bayam }\end{array}$ & 30 & 37 & 4.5 & 45 & 40 & 13.500 \\
\hline $\begin{array}{c}\text { Bubur bayi Reguler } \\
6 \text { bulan }+\end{array}$ & $\begin{array}{l}\text { Sop Ayam } \\
\text { Wortel }\end{array}$ & 30 & 37 & 4.5 & 45 & 40 & 13.500 \\
\hline $\begin{array}{c}\text { Bubur bayi Organic } \\
6 \text { bulan }+\end{array}$ & Pisang & 33 & 36 & 4.5 & 40 & 50 & 29.500 \\
\hline $\begin{array}{c}\text { Bubur bayi Organic } \\
6 \text { bulan }+\end{array}$ & Kacang Hijau & 30 & 36 & 5 & 35 & 20 & 29.500 \\
\hline $\begin{array}{c}\text { Bubur bayi Organic } \\
6 \text { bulan }+\end{array}$ & Beras Merah & 30 & 36 & 5 & 35 & 25 & 29.500 \\
\hline $\begin{array}{c}\text { Bubur bayi WGain } 6 \\
\text { bulan }+\end{array}$ & Ayam Bayam & 40 & 25 & 4.5 & 40 & 35 & 23.500 \\
\hline $\begin{array}{c}\text { Bubur bayi WGain } 6 \\
\text { bulan }+\end{array}$ & Ayam Sayur & 40 & 25 & 4.5 & 40 & 35 & 23.500 \\
\hline Bubur bayi Goodmil & Beras Merah & 30 & 27 & 4 & 50 & & \\
\hline
\end{tabular}




\begin{tabular}{|c|c|c|c|c|c|c|c|}
\hline $\begin{array}{l}\text { Kategori Pemilihan } \\
\text { Alternatif }\end{array}$ & Rasa & $\begin{array}{c}\text { Protei } \\
\text { n } \\
\text { (pers } \\
\text { en } \\
\text { AKG) }\end{array}$ & $\begin{array}{c}\text { Karbohi } \\
\text { drat } \\
\text { (gram) }\end{array}$ & $\begin{array}{c}\text { Lema } \\
\mathbf{k} \\
\text { (gram } \\
\text { ) }\end{array}$ & $\begin{array}{c}\text { Zat Besi } \\
\text { (persen } \\
\text { AKG) }\end{array}$ & $\begin{array}{c}\text { Zing/se } \\
\text { ng } \\
\text { (persen } \\
\text { AKG) }\end{array}$ & Harga \\
\hline 6 bulan + & Pisang & & & & & 40 & 18.000 \\
\hline $\begin{array}{c}\text { Bubur bayi Goodmil } \\
6 \text { bulan }+\end{array}$ & Wortel Labu & 30 & 27 & 4 & 50 & 40 & 18.000 \\
\hline $\begin{array}{l}\text { Bubur bayi Goodmil } \\
6 \text { bulan }+\end{array}$ & $\begin{array}{l}\text { Beras Merah } \\
\text { Ayam }\end{array}$ & 30 & 27 & 4 & 50 & 40 & 22.000 \\
\hline $\begin{array}{c}\text { Bubur bayi Goodmil } \\
6 \text { bulan }+\end{array}$ & Beras Merah & 30 & 27 & 4 & 50 & 40 & 45.000 \\
\hline
\end{tabular}

Tabel 3.3 Matrik Alternatif

\begin{tabular}{lllllll}
\hline & C1 & C2 & C3 & C4 & C5 & C6 \\
\hline A1 & 30 & 37 & 4.5 & 40 & 40 & 13.500 \\
A2 & 30 & 36 & 4.5 & 40 & 35 & 13.500 \\
A3 & 30 & 37 & 4.5 & 45 & 40 & 13.500 \\
A4 & 30 & 37 & 4.5 & 45 & 40 & 13.500 \\
A5 & 30 & 37 & 4.5 & 45 & 40 & 13.500 \\
A6 & 33 & 36 & 4.5 & 40 & 50 & 29.500 \\
A7 & 30 & 36 & 5 & 35 & 20 & 29.500 \\
A8 & 30 & 36 & 5 & 35 & 25 & 29.500 \\
A9 & 40 & 25 & 4.5 & 40 & 35 & 23.500 \\
A10 & 40 & 25 & 4.5 & 40 & 35 & 23.500 \\
A11 & 30 & 27 & 4 & 50 & 40 & 18.000 \\
A12 & 30 & 27 & 4 & 50 & 40 & 18.000 \\
A13 & 30 & 27 & 4 & 50 & 40 & 22.000 \\
A14 & 30 & 27 & 4 & 50 & 40 & 45.000 \\
\hline
\end{tabular}

Keterangan :

An : Alternatif Bubur Bayi

C : Kriteria

C1 : Protein

C2 : Karbohidrat C3 : Lemak

C4 : Zat Besi C5 : Zing/Seng C6 : Harga

\subsection{Hasil Penelitian}

\subsubsection{Kriteria}

Dalam penelitian ini kriteria penilaian yang digunakan ada 6 yaitu:

Tabel 3.4 Kriteria

\begin{tabular}{cl}
\hline Kode Kriteria & Kriteria \\
\hline C1 & Protein
\end{tabular}




\begin{tabular}{cl}
\hline Kode Kriteria & Kriteria \\
\hline C2 & Karbohidrat \\
C3 & Lemak \\
C4 & Zat Besi \\
C5 & Zing/Seng \\
C6 & Harga \\
\hline
\end{tabular}

\subsubsection{Tingkat Kepentingan}

Penentuan bobot berdasarkan nilai tingkat kepentingan masing-masing kriteria, tingkat kepentingan setiap kriteria dinilai dengan 1 sampai 5 . Tingkat kepentingan dapat dilihat pada tabel dibawah ini:

Tabel 3.5 Tingkat Kepentingan

\begin{tabular}{cc}
\hline Tingkat Kepentingan & Nilai \\
\hline Tidak Penting & 1 \\
Kurang Penting & 2 \\
Cukup Penting & 3 \\
Penting & 4 \\
Sangat Penting & 5 \\
\hline
\end{tabular}

Nilai bobot atau bobot awal (W) masing-masing kriteria telah ditentukan oleh Angka Kecukupan Gizi dan standart keperluan bayi yang ditentukan oleh peneliti bubur bayi pada Tabel 3.6

\begin{tabular}{cc} 
Tabel 3.6 Pembobotan Kriteria \\
\hline Kode & Bobot \\
\hline C1 & 5 \\
C2 & 5 \\
C3 & 5 \\
C4 & 4 \\
C5 & 4 \\
C6 & 3 \\
\hline
\end{tabular}

\subsubsection{Perbaikan Bobot Perkriteria}

Setelah mendapatkan nilai bobot pada masing-masing kriteria maka dilakukan perbaikan bobot dari nilai bobot awal. Perbaikan bobot dengan rumus sebagai berikut:

$$
W W_{j}=\frac{w w j j}{\Sigma w w j j} \quad \text { ATAU } \quad W W_{j j}=\frac{C C}{C 1+\ldots 5}
$$


Keterangan :

$W W_{j j} \quad$ : Bobot Atribut

$\sum W W_{j j}$ : Penjumlahan Bobot Atribut Tabel IV.7.

Berikut merupakan hasil dari perbaikan bobot pada setiap kriteria pada Tabel IV.7 Bobot Preferensi

\begin{tabular}{ll}
\hline Kode & Nilai \\
\hline W1 & 0,192307692 \\
W2 & 0,192307692 \\
W3 & 0,192307692 \\
W4 & 0,153846153 \\
W5 & 0,153846153 \\
W6 & 0,115384615 \\
\hline
\end{tabular}

\subsubsection{Perhitungan Nilai Vektor (S)}

Setelah dilakukan perbaikan bobot, dilakukan perhitungan nilai vektor (S), dengan memangkatkan dan mengalikan nilai masing-masing kriteria tersebut dengan bobot yang sudah diperbaiki sebelumnya. Bedasarkan pada Tabel IV.8 merupakan hasil dari penulis melakukan observasi langsung lalu mengumpulkan data-data Spesifikasi Kemasan pada produk Bubur Bayi.

Tabel 3.8 Data Penilaian Bubur Bayi

\begin{tabular}{ccccccc}
\hline Alternatif & \multicolumn{6}{c}{ Kode Kriteria } \\
\cline { 2 - 7 } & C1 & C2 & C3 & C4 & C5 & C6 \\
\hline A1 & 30 & 37 & 4.5 & 40 & 40 & 13.500 \\
A2 & 30 & 36 & 4.5 & 40 & 35 & 13.500 \\
A3 & 30 & 37 & 4.5 & 45 & 40 & 13.500 \\
A4 & 30 & 37 & 4.5 & 45 & 40 & 13.500 \\
A5 & 30 & 37 & 4.5 & 45 & 40 & 13.500 \\
A6 & 33 & 36 & 4.5 & 40 & 50 & 29.500 \\
A7 & 30 & 36 & 5 & 35 & 20 & 29.500 \\
A8 & 30 & 36 & 5 & 35 & 25 & 29.500 \\
A9 & 40 & 25 & 4.5 & 40 & 35 & 23.500 \\
A10 & 40 & 25 & 4.5 & 40 & 35 & 23.500 \\
A11 & 30 & 27 & 4 & 50 & 40 & 18.000 \\
A12 & 30 & 27 & 4 & 50 & 40 & 18.000 \\
A13 & 30 & 27 & 4 & 50 & 40 & 22.000 \\
A14 & 30 & 27 & 4 & 50 & 40 & 45.000 \\
\hline
\end{tabular}


Perhitungan nilai vektor $(\mathrm{S})$ dengan rumus:

$$
\mathrm{Ss}_{i}=\Pi_{j j}^{n n}=1 X X \quad i i j j W_{j}
$$

Keterangan :

$S S_{i i} \quad$ : Hasil Normalisasi Matrik

$X X_{i i j j} \quad$ : Nilai Variabel dari alternatif pada setiap atribut

$W W_{j j} \quad$ : Nilai BobotKriteria

n : Banyaknya Kriteria

i : Nilai Alternatif

j : Nilai Kriteria

Pada Tabel IV.9 merupakan Preferensi Vektor S yaitu hasil nilai dari setiap alternatif serta jumlah total seluruh nilai vektor $\mathrm{S}$.

Tabel 3.9 Nilai Preferensi Vektor S

\begin{tabular}{cc}
\hline Preferensi alternatif & Nilai Vektor S \\
\hline S1 & 47,948 \\
S2 & 48,568 \\
S3 & 49,718 \\
S4 & 49,718 \\
S5 & 49,718 \\
S6 & 55,020 \\
S7 & 46,905 \\
S8 & 48,543 \\
S9 & 49,081 \\
S10 & 49,081 \\
S11 & 68,803 \\
S12 & 68,803 \\
S13 & 48,306 \\
S14 & 52,464 \\
Total & $\mathbf{7 3 2 , 6 7 6}$ \\
\hline
\end{tabular}

\subsubsection{Perhitungan Nilai Vektor (V)}

Setelah mendapatkan nilai Vektor (S) langkah selanjutnya yaitu menentukan nilai vektor (V) yaitu, membagi preferensi setiap alternatif dengan jumlah total vektor $S$ dengan rumus:

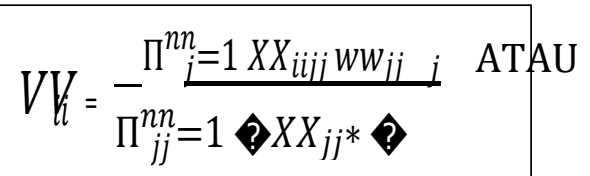

$$
V V_{1}=\frac{S S 1}{S 1+\ldots S 3}
$$




\section{Keterangan :}

$V_{i ̈} \quad$ : Hasil preferensi alternatif ke-i

$X X_{i i j j}$ : Nilai Variabel dari alternatif pada setiap atribut

$W W_{j j}$ : Nilai Bobot Kriteria

n : Banyaknya Kriteria

i : Nilai Alternatif

j : Nilai Kriteria

* : Banyaknya kriteria yang telah dinilai pada vektor S

Tabel 3.9 Hasil nilai Vektor V pada setiap alternatif.

\begin{tabular}{cc}
\hline Preferensi Alternatif & Nilai Vektor V \\
\hline V1 & 0,06544 \\
V2 & 0,06628 \\
V3 & 0,06785 \\
V4 & 0,06785 \\
V5 & 0,06785 \\
V6 & 0,07509 \\
V7 & 0,06401 \\
V8 & 0,06625 \\
V9 & 0,06698 \\
V10 & 0,06698 \\
V11 & 0,09390 \\
V12 & 0,09390 \\
V13 & 0,06593 \\
V14 & 0,07160 \\
\hline
\end{tabular}

\subsubsection{Menentukan Hasil}

Langkah terakhir yaitu merangking data yang telah dihitung berdasarkan nilai vektor $\mathrm{V}$ dari nilai yang terbesar hingga yang terkecil.

Tabel 3.10 Rangking Nilai Alternatif

\begin{tabular}{cc}
\hline Nilai & Alternatif \\
\hline 0,09390 & A11 \\
0,09390 & A12 \\
0,07509 & A6 \\
0,07160 & A14 \\
0,06785 & A3 \\
0,06785 & A4 \\
0,06785 & A5
\end{tabular}




\begin{tabular}{cc}
\hline Nilai & Alternatif \\
\hline 0,06698 & A9 \\
0,06698 & A10 \\
0,06628 & A2 \\
0,06625 & A8 \\
0,06593 & A13 \\
0,06544 & A1 \\
0,06401 & A7 \\
\hline
\end{tabular}

Maka sesuai dengan hasil perhitungan menggunakan metode Weighted Product untuk penyeleksian bubur bayi terbaik pada Tabel 3.10 didapatkan 2 alternatif terbaik yaitu A11 dengan nilai 0,09390 dan A12 dengan nilai 0,09390.

A11 = Bubur Bayi Rasa Beras Merah Pisang

A12 = Bubur Bayi Rasa Wortel Labu

\section{SIMPULAN}

Jadi dapat disimpulkan dari hasil perhitungan Metode Weighted Product yang terdiri dari beberapa Kriteria dan Variable Alternatif yang didapat, telah melalui beberapa tahap perhitungan, mulai dari penentuan Alternatif dan Kriteria, Kriteria Seleksi Bubur Bayi, Tingkat Kepentingan Bobot, Pembobotan Kriteria, Perhitungan Vektor hingga Perangkingan, dapat disimpulkan bahwa Bubur Bayi Terbaik jatuh pada Bubur Bayi rasa Beras Merah Pisang dan rasa Wortel Labu. Perhitungan SPK dengan menggunakan metode Weighted Product teruji efektif dan sangat membantu dalam pengambilan keputusan.

\section{DAFTAR PUSTAKA}

[1] H. R. Hatta, M. Rizaldi, and D. M. Khairina, "Penerapan Pen erapan Metode Weighted Product U ntuk Pemilihan Lokasi L ahan Baru Pemakaman Muslim Dengan Visualisasi Google Maps," TEKNOSI, vol. 02, no. 03, pp. 85-94, 2016.

[2] D. C. Yoni and H. Mustafidah, "Penerapan Metode WP ( Weighted Product ) Untuk Pemilihan Mahasiswa Lulusan Terbaik di Fakultas Teknik Universitas Muhammadiyah Purwokerto," JUITA, vol. IV, no. 1, pp. 22-27, 2016.

[3] D. L. Kurniasih, "Sistem Pendukung Keputusan Pemilihan Laptop dengan Metode TOPSIS," Pelita Inform. Budi Darma, vol. III, no. April, pp. 6-13, 2013.

[4] H. Supriyono and C. P. Sari, "Rumah Tinggal Menggunakan Metode Weighted Product," J. Ilmu Komput. dan Inform. Pemilihan, vol. 1, no. 1, pp. 23-28, 2015.

[5] Y. Zai, Mesran, and E. Buulolo, "Sistem Pendukung Keputusan untuk 
menentukan Buah Rambutan dengan Kualitas Terbaik menggunakan Metode Weighted Product (WP)," Media Inform. Budidarma, vol. 1, no. 1, pp. 8-11, 2017.

[6] N. Nurjannah, Z. Arifin, and D. M. Khairina, "Sistem Pendukung Keputusan Pembelian Sepeda Motor Dengan Metode Weighted Product," J. Inform. Mulawarman, vol. 10, no. 2, pp. 2-6, 2015.

[7] S. Susliansyah, R. R. Aria, and S. Susilowati, "Sistem Pemilihan Laptop Terbaik Dengan Menggunakan Metode Weighted Product (Wp)," J. Techno Nusa Mandiri, vol. 16, no. 1, pp. 15-20, 2019.

[8] D. C. Simanjuntak, L. R. Silalahi, and K. B. Rajagukguk, "Sistem Pendukung Keputusan Pemilihan Makanan Pada Bayi 5 Tahun Menerapkan Metode MOORA dan WASPAS," in SENSASI, 2018, pp. 680-689.

[9] E. Ridhawati and L. Julianti, "Pemilihan Makanan Pendamping ASI Pada Batita Dengan Menerapkan Metode TOPSIS," SIMADA (Jurnal Sist. Inf. Manaj. Basis Data), vol. 1, no. 1, p. 31, 2018.

[10] D. Febrina, D. M. Nst, and N. K. Dewi, "Penerapan Metode MOORA Dan WASPAS Dalam Mendukung Keputusan Pemilihan Susu Formula Terbaik," in Seminar Nasional Sains \& Teknologi Informasi, 2018, pp. 515525.

[11] R. Rachmatullah and H. A. Setyadi, "Implementasi Metode AHP dan WP dalam Sistem Pendukung Keputusan Pemilihan Susu Formula Balita," J. Speed, vol. 10, no. 3, pp. 55-60, 2018. 